\title{
Impact of wastewater treatment plant discharge on the contamination of river biofilms by pharmaceuticals and antibiotic resistance
}

\author{
Elodie Aubertheau a, Thibault Stalder b,c, Leslie Mondamert a, Marie-Cécile Ploy b, \\ Christophe Dagot b,c, Jérôme Labanowski a,* \\ a University of Poitiers, UMR CNRS 7285 IC2MP, Department of Water and Geochemistry, ENSIP, 1 Rue Marcel Doré, TSA 41105, 86073 \\ Poitiers Cedex, France \\ b University of Limoges, INSERM UMR-S1092, Faculté de Médecine, 2 rue du Docteur Marcland, 87065 Limoges Cedex, France \\ c University of Limoges, GRESE EA4330, ENSIL, 16 rue Atlantis, 87068 Limoges Cedex, France
}

\section{HIGHLIGHTS}

- River biofilms accumulate few ng/g of pharmaceuticals.

- No evident relationship exists between WWTP specificities and biofilm contamination.

- Distance enhances the decrease of pharmaceutical concentrations in the biofilms.

- Changes occur in the bacterial diversity of biofilms exposed to WWTPs.

-WWTPs discharges causes a significant enrichment of Class 1 resistance integrons.

\begin{abstract}
Wastewater treatment plants (WWTPs) are one of the main sources of pharmaceutical residue in surface water. Epilithic biofilms were collected downstream from 12WWTPs of various types and capacities to study the impacts of their discharge through the changes in biofilm composition (compared to a corresponding upstream biofilm) in terms of pharmaceutical concentrations and bacterial community modifications (microbial diversity and resistance integrons). The biofilm is a promising indicator to evaluate the impacts of WWTPs on the surrounding aquatic environment. Indeed, the use of biofilms reveals contamination hot spots. All of the downstream biofilms present significant concentrations (up to $965 \mathrm{ng} / \mathrm{g}$ ) of five to 11 pharmaceuticals (among the 12 analysed). Moreover, the exposition to the discharge point increases the presence of resistance integrons (three to 31 fold for Class 1) and modifies the diversity of the bacterial communities (for example cyanobacteria). The present study confirms that the discharge from WWTPs has an impact on the aquatic environment.
\end{abstract}

\section{Introduction}

The presence of pharmaceuticals has been reported worldwide in natural waters at concentration levels of ng/L to a few $\mu \mathrm{g} / \mathrm{L}$ (Ashton et al., 2004; Fernández et al., 2010; Boxall et al., 2008). Indeed, many classes of pharmaceuticals enter into surfacewater and groundwater directly or indirectly through consumption of human and animal medicine or anthropogenic activities such as sewage discharge, livestock breeding, and fertilizing (Kümmerer, 2004). Recent studies on the relative contributions of various sources of pharmaceuticals suggest that the contribution of urban wastewater treatment plants (WWTPs) is one of the most significant contributors (Jelić et al., 2012; Miège et al., 2009). Indeed the removal of pharmaceuticals and their metabolites by WWTPs is incomplete (Castiglioni et al., 2006) and depends on several parameters, such as treatment processing, operational conditions employed, and substance properties (Bartelt-Hunt et al., 2009; Clara et al., 2005). Therefore, removal efficiencies can vary significantly from compound to compound, from plant to plant, and within a plant at different time periods (Vieno et al., 2007).

The release of pharmaceuticals byWWTPs has now become a major environmental issue. Many studies have observed that the concentration of pharmaceuticals increases from two to 10-fold downstream from the discharge points of WWTPs (Baker and Kasprzyk-Hordern, 2013; Batt et al., 2006; Gabet-Giraud et al., 2014; Lindqvist et al., 2005). It has also been shown that continuous exposure to such low (i.e., subtoxic) concentrations of certain pharmaceuticals can cause unexpected consequences and unintended effects on non-target species, and induce undesirable effects (e.g., endocrine disrupting effects) on 
ecosystems (Burger and Gochfeld, 2001; Gagné and Blaise, 2004; Ricart et al., 2010; Sui et al., 2015). An example of fish population disturbance (i.e., intersex and male-biased sex ratio) was found in a French river downstream from a pharmaceutical manufacturing discharge (Sanchez et al., 2011). It was also reported that pharmaceuticals can alter microbial communities by suppressing algal growth and microbial respiration in biofilms (Ricart et al., 2010; Rosi-Marshall et al., 2013). More recently, Huerta et al. (2016) have shown that river biofilms can accumulate pharmaceuticals. River biofilms could represent up to $90 \%$ of the total microbial flora (bacteria, algae, fungi) and are a significant primary production source (Pyl'nik et al., 2007). Hence, the contamination of biofilms may be responsible for bioaccumulation (Berlioz-Barbier et al., 2014; Ramirez et al., 2009) and/or biomagnification problems (Ruhí et al., 2016) within the trophic level. Furthermore, the accumulation of active molecules, such as antibiotics, could affect the selection of bacterial consortium into the biofilm and, especially, bacterial resistance.

Recent advances show that chronic exposure to antibiotics, even at very low concentrations, can promote and maintain a pool of resistance genes in microbial communities (Balcázar et al., 2015; Martinez, 2009). Antibiotic resistance genes may proliferate through horizontal transfer processes between individual cells or species (Aminov, 2011). The integrons platform-cassette ensemble, consisting of a site-specific recombinase, a promotor, a gene coding for an integrase and a series of small DNA units (cassettes), have recently been highlighted in the dissemination of resistance in bacteria (Gillings et al., 2015). A growing number of studies have used Class 1 integrons to evaluate the resistance potential in natural or engineered environments (Khan et al., 2013; Martinez, 2009; Stalder et al., 2013). Class 1 integrons are considered to be a biomarker of an anthropogenic impact, such as the antibiotic resistance (Gillings et al., 2008, Stalder et al., 2012). Indeed, WWTPs are an ideal place for horizontal gene transfer due to the joint presence of antibiotics and the high density of bacteria (Rizzo et al., 2013). The large level of discharge from WWTPs may also contribute to the transfer and transport of antibiotic resistant bacteria (LaPara et al., 2011) and antibiotic resistance genes throughout watersheds (Aminov and Mackie, 2007; Baquero et al., 2008; Drury et al., 2013; Wellington et al., 2013). Nevertheless, it was recently proposed that the effect of antibiotic pollution on river biofilm microbial communities also underlies the resistance to these compounds in the rivers (Balcázar et al., 2015).

In the context of the European Water Framework Directive, the water policy is looking for studies and concrete feedback on the impact of wastewater management on water resources with a view to formulating a recommendation on emerging issue such as pharmaceuticals (Directive 2000/60/EC, 2000). Thus, the present study proposes a comparison between the contaminations of river biofilms sampled downstream from WWTPs of various types and capacities. The impact of WWTPs was evaluated through the changes in biofilm composition (compared to a corresponding upstream biofilms) in term of pharmaceutical concentrations and bacterial community modifications (microbial diversity and resistance integrons).

\section{Materials and methods}

\subsection{Description of the studied sites}

The Vienne River watershed is located in the central part of France, on the northwestern plateau of the Massif Central, which is connected with the Loire River. This region is mainly rural and weakly anthropized (EPTB Vienne, 2011). Twelve sites (corresponding to the principal urban areas) and their WWTPs were investigated (Fig. SI-1, Supplementary information). The main characteristics of the corresponding WWTPs are described in the Table 1. Eight WWTPs use the activated sludge process (AS) (from 2500 to 285,000 population equivalent (PE)) and four WWTPs use the activated sludge process followed by a reed-planted bed filter (AS + RPBF) (from 1200 to $9000 \mathrm{PE}$ ). All of these WWTPs are in compliance with the French framework related to urban wastewater (in compliance with the European Directive 91/271/EEC, 1991). Nevertheless, five WWTPs have an effective daily flowrate 
that is higher than their nominal capacity ('StLeo', 'StPri', 'Lim', 'StVic', and 'StJu'; Table 1). All of these WWTPs release their effluents into the Vienne River. Six WWTPs also receive hospital effluents (mainly from geriatric units) in addition to their urban effluents. Only 'Lim' (1537 beds) and 'Chatel' (314 beds) hospitals have several units such as surgery and paediatrics. Table SI-1 shows the mean daily flow rate at the sampling point. Along the Vienne River, the flow rate increases progressively with the distance from the spring.

\subsection{Biofilm collection and characterization}

Two biofilm samples were collected in the river at each site. A first biofilm sample was collected upstream from the discharge point to serve as a reference (named "upstream") and a second biofilm sample was collected immediately downstream from the WWTP outfall (named ' $0 \mathrm{~m}$ '). The term "biofilm" refers to the cells and the surrounding matrix (i.e., organic and inorganic components), considering both active biological uptake and passive physical sorption (Huerta et al., 2016). At six sampling sites, a second biofilm sample was collected farther from the discharge point (noted ' $10 \mathrm{~m}$ ') and at 'Chatel', an additional sample was collected $100 \mathrm{~m}$ downstream from the WWTPs (noted '100 $\mathrm{m}$ '). At each site, five to 10 rocks were collected randomly in an area of $2 \mathrm{~m} 2$ (to provide a representative sampling), submerged all over the year. The rocks were collected near the riverbank at 50-100 cm depth the day of sampling. It should be noted that the river depth increases gradually along the watershed however no gradual increase of the biofilm contamination was observed according to the location of the biofilm along the river.

The biofilm was removed by scraping the surface with a sterile toothbrush that used only once. The biofilm suspensions were transferred into aseptic plastic bottles and stored in a cool-box until the end of the sampling day. All the biofilms were collected during three consecutive days of sampling in July 2011. The biofilm samples were then freeze-dried (Cosmos 20 k, Cryotec, France) and grinded (Ultraturrax ${ }^{\circledR}$, IKA, Staufen, Germany) to provide homogeneous samples prior to analysis.

Table 1. Process and capacity of the selected WWTPs.

\begin{tabular}{|c|c|c|c|c|c|c|}
\hline \multirow[t]{2}{*}{ City } & \multirow[t]{2}{*}{ Process } & \multirow{2}{*}{$\begin{array}{l}\text { Commissioning } \\
\text { (compliance) }\end{array}$} & \multicolumn{2}{|l|}{ Capacity } & \multirow{2}{*}{$\begin{array}{l}\text { Effective } \\
\text { daily } \\
\text { flow rate } \\
\left(\mathrm{m}^{3} / \mathrm{d}\right) \text { in } \\
2012\end{array}$} & \multirow{2}{*}{$\begin{array}{l}\text { Hospital } \\
\text { bed } \\
\text { capacity }\end{array}$} \\
\hline & & & $\begin{array}{l}\text { Population } \\
\text { equivalent } \\
(\mathrm{PE})\end{array}$ & $\begin{array}{l}\text { Flow } \\
\text { rate } \\
\left(\mathrm{m}^{3} / \mathrm{d}\right)\end{array}$ & & \\
\hline 'IB' & AS & 1994 & 2250 & 500 & 198 & - \\
\hline 'StLeo' & AS & 1993 & 2500 & 458 & 1236 & 93 beds \\
\hline 'LLC' & AS & 1975 (2005) & 3500 & 600 & $\overline{378}$ & - \\
\hline 'Conf' & AS & 2004 & 12,000 & 1400 & 654 & 82 beds \\
\hline 'Chin' & AS & 1998 & 13,500 & 2130 & 1233 & $\begin{array}{l}661 \\
\text { beds }\end{array}$ \\
\hline 'Stju' & AS & 2000 & 30,000 & 7000 & 7066 & $\begin{array}{l}393 \\
\text { beds }\end{array}$ \\
\hline 'Chatel' & AS & 2002 & 92,833 & 10,400 & 4978 & $\begin{array}{l}314 \\
\text { beds }\end{array}$ \\
\hline 'Lim’ & AS & 2006 & 285,000 & 81,420 & $\underline{92,560}$ & $\begin{array}{l}1537 \\
\text { beds }\end{array}$ \\
\hline 'StVic' & $\mathrm{AS}+\mathrm{RPBF}$ & 1996 & 1200 & 180 & 319 & - \\
\hline 'StPri' & $\mathrm{AS}+\mathrm{RPBF}$ & 2002 & 1900 & 285 & $\overline{447}$ & - \\
\hline 'Chab' & $\mathrm{AS}+\mathrm{RPBF}$ & 2011 & 3300 & 605 & $\overline{285}$ & - \\
\hline 'Chauv' & $\mathrm{AS}+\mathrm{RPBF}$ & 2001 & 9000 & 1470 & 957 & - \\
\hline
\end{tabular}

AS: activated sludge; RPBF: reed-planted bed filter; PE: population equivalent; WWTPs with effective daily flow rates exceeding nominal capacity are underlined.

\subsection{Pharmaceutical analysis}

Twelve common pharmaceuticals usually quantified in French rivers were selected for the present study (Table 2). The extraction of pharmaceuticals from the biofilm sampleswas performed using the pressurized liquid extraction (PLE) technique with an accelerated solvent extractor (ASETM 350, 
Thermo Fisher Scientific ${ }^{\circledR}$ Inc., Waltham, USA). The extraction cells were then filled with a mixture of $0.5 \mathrm{~g}$ of the biofilm sample and $2 \mathrm{~g}$ of diatomaceous earth (Sigma Aldrich $®$ ). The extractions were carried out with methanol/water $(1 / 2 ; \mathrm{v} / \mathrm{v})$ at $80^{\circ} \mathrm{C}$ and 100 bars, five static cycles of $4 \mathrm{~min}$ and a rinse volume of $60 \%$. The samples were then purified on Oasis ${ }^{\circledR}$ HLB cartridges $(6 \mathrm{~cm} 3,200 \mathrm{mg}$ sorbent; Waters ${ }^{\circledR}$, Milford, USA) and eluted with LC-MS grade methanol (Autotrace ${ }^{\mathrm{TM}} 150$, Thermo Scientific, Waltham, USA). Finally, the extracts were evaporated to dryness under a gentle steam of nitrogen and then recovered in a methanol/water mixture $(10 / 90 ; \mathrm{v} / \mathrm{v})$. The pharmaceuticals were separated using Ultra Performance Liquid Chromatography (Acquity; Waters ${ }^{\circledR}$, Milford, USA) on an Acquity UPLC® BEH C18 column $\left(2.1 \times 100 \mathrm{~mm}, 1.7 \mu \mathrm{m}\right.$; Waters ${ }^{\circledR}$, Milford, USA $)$ with a gradient composed of methanol and water, both acidified with $0.1 \%$ formic acid. The liquid chromatography was coupled to a triple-quadrupole mass spectrometer (Xevo ${ }^{\mathrm{TM}} \mathrm{TQ}$, Waters ${ }^{\circledR}$, Milford, USA) using an electrospray ion source operated in both positive and negative modes (depending on the molecules). Table SI-2 shows the fragmentation ions selected for each molecule. Every pharmaceutical concentration quantified in the biofilm is expressed in $\mathrm{ng} / \mathrm{g}$ of dry biofilm. The values were obtained with an increasing standard addition in the biofilm extract. Due to the complexity of finding a biofilm without any pharmaceutical contamination, the determination of the limits of quantification (LOQ) was performed with the addition of stable standard isotopes in a biofilm matrix collected in the Vienne river basin. This method shows that the limit of quantification ranges from 0.18 to $1.13 \mathrm{ng} / \mathrm{g}$ (Table SI-3). Furthermore, Table SI-3 presents the global recoveries (extraction and purification). It is worth noting that the extraction method used is not the best for all pharmaceuticals but constitutes a compromise necessary for a multi-residues analysis.

\subsection{DNA extraction}

Two millilitres of freshly collected biofilms were pelleted at $15,000 \mathrm{~g}$ for $10 \mathrm{~min}$ and stored at $-80{ }^{\circ} \mathrm{C}$, and the total DNA was extracted using a FastDNA ${ }^{\circledR}$ spin kit for faeces, according to the manufacturer instructions. The extraction was performed using the FastPrep ${ }^{\circledR} 120$ Instrument (MP Biomedicals ${ }^{\circledR}$, California, USA). The quality of the extracted DNA was verified by electrophoresis through $0.8 \%(\mathrm{w} / \mathrm{v})$ agarose gel and quantified with a Nanodrop spectrophotometer (ThermoScientific $®$, Waltham, USA) before being stored at $-20^{\circ} \mathrm{C}$ until analysis.

\subsection{Bacterial community analysis}

The V3 and V4 regions of the 16S rRNA encoding gene were chosen to analyse bacterial diversity, using the universal bacterial primers 339F (CTCCTACGGGAGGCAGCAG) and 339R (TTGTGCGGGCCCCCGTCAATT), which target the V3 and V4 variable regions of the 16S rRNA gene. Pyrosequencing and PCR were conducted by the Molecular Research LB Lab (http://www.mrdnalab.com/) using standard laboratory procedures and a 454 FLX Sequencer (454 Life Sciences, Roche Applied Science $\left.{ }^{8}\right)$. The Q25 derived from the sequencing process was processed using a proprietary analysis pipeline. After trimming the sequences from their barcodes and primers, sequences shorter than $300 \mathrm{pb}$, or containing ambiguous base calls, or with homopolymer runs exceeding $6 \mathrm{bp}$ were removed. Then sequences were denoised and the chimeras were removed. Finally, the opensource bioinformatics pipeline QIIME (Caporaso et al., 2010)was used to, 1) define the operational taxonomic units (OTU) after removal of the singleton sequences, clustering at 3\% divergence $(97 \%$ similarity), 2) taxonomically classify the OTUs using BLASTn against the GreenGenes database, and 3) compile into each taxonomic level. Before the diversity analysis, the OTU table was sub-sampled (rarefied) 1000 times in order to avoid bias due to different sequencing depths (the samples 'StLeo 0 m', and 'StJu upstream' were filtered out due to their low sequencing depths).

\subsection{Integrons detection and quantification}


Class 1, 2, and 3 integrons were detected using the quantitative realtime PCR method described by Barraud et al. (2010). The 16S rRNA encoding gene was quantified by SYBR green assay using the universal primers 338F and 518R, as described in Park and Crowley (2006). The assays were done in triplicate with a MX3005P real-time detection system (Stratagene $\AA$ ). For accurate quantification, the genes intI1, intI2, intI3, corresponding to the 3 classes of integrons and 16S rRNA encoding genes were embedded in a single plasmid. The plasmid standard for the absolute gene quantification was constructed as described in Stalder et al. (2014). Briefly, the intI2 and intI3 genes from the pGEM-T Easy::intI2 and pBAD18::intI3 plasmids (Barraud et al., 2010) were cloned into pTRC99A::intI1 (Demarre et al., 2007). The 16S rRNA-encoding gene fragment amplified from Escherichia coli MG1656 with the 338F and 518R primers was sub-cloned into the pTRC99A::intI1::intI2::intI3. This plasmid allowed us to construct a full standard curve, between 103 and 108 copy numbers, in duplicate, in each qPCR run. In order to avoid qPCR inhibitor effects, the total DNA samples were diluted to the point where quantification was unaffected. Based on the Ribosomal RNA Database, the average number of $16 \mathrm{~S}$ rRNA encoding genes per bacterium is currently estimated at 4.1 (Klappenbach et al., 2001; Stalder et al., 2012). The 16S rRNA encoding gene quantities were thus divided by this value to estimate the bacterial cell numbers (Hardwick et al., 2008). Results of the estimated bacterial cell number are presented in the Table SI-6. Class 1, 2 and 3 integron quantifications were normalized (normalized copy number) by dividing the absolute quantification of each intI gene by the molecularly estimated bacterial cell number. Moreover, in order to minimize experimental biases, all quantifications of the intI and 16S rRNA encoding genewere performed during the same qPCR run with the plasmid containing the four genes.

\subsection{Exploitation of data}

\subsubsection{Statistical analysis}

Statistical tools were applied to the data set using XLSTAT ® (Addinsoft Software, Paris, France) and R (http://www.R-project.org/) software. Multidimensional scaling (MDS) was used to compare the biofilm samples based on all pharmaceutical concentrations. First, a dissimilarity matrix (from Euclidean distance) on the biofilms collected immediately downstream from the WWTPs was established. Then, MDS was applied to the dissimilarity matrix to obtain the coordinates of the samples in a representative two-dimensional space. The algorithm used for the MDS calculation was SMACOF (Scaling by MAjorizing a Convex Function), which minimizes the normalized stress. Kruskal's stress indicates the quality of the representation (the smaller the value, the better the quality of the representation; Kruskal's stress must tend to 0.05 in order to be significant; a value higher than 0.2 indicates a bad representation) (Kruskal, 1964). It is worth noting that the MDS was established on centred and standardized data according to the following calculation:

([selected compound] - geometric mean) / (standard deviation)

Geometric mean subtraction is necessary to perform MDS and to ensure that the principal components describe the direction of the maximum variance.

Nonmetric multidimensional scaling (nMDS) was used on bacterial diversity data to evaluate the overall differences in the microbial community structure (Paliy and Shankar, 2016). The Kruskal's algorithm was chosen for the nMDS calculation and applied on a Bray-Curtis matrix of dissimilarities. The BrayCurtis distance is generally preferred to the Euclidean distance for molecular ecology data sets. As for MDS, a stress parameter is computed to measure the lack of fit between objects distances in the nMDS ordination space and the calculated dissimilarities among objects. The nMDS algorithm then iteratively repositions the objects in the ordination space (in two dimension-2D space) to minimize the stress function.

\subsubsection{Enrichment factor}


Enrichment factors (EFs) were used to describe the impact of the discharge from WWTPs on the biofilm located downstream. The EFs were calculated using background values established for each site through the measurement of upstream biofilms. The EF was calculated as follows:

- For pharmaceuticals and integrons:

$$
\mathrm{EF}=\log 10\left([\text { compound }]_{\text {downstream }} /[\text { compound }]_{\text {upstream }}\right)
$$

where $\log 10(\mathrm{EF})$ is the logarithm of the enrichment factor; [compound]upstream is the concentration of the selected pharmaceutical in the upstream biofilm and [compound]downstream is the concentration of the selected pharmaceutical in the corresponding downstream biofilm. A positive value indicates an increase in the concentration of the downstream biofilm whereas a negative value indicates a decrease in this concentration.

- For bacterial diversity:

$(\mathrm{EF})=(\text { percentage of the OUT })_{\text {downstream }}-(\text { percentage of the OUT })_{\text {upstream }}$

A positive value indicates a higher percentage of the OTU in the downstream biofilm whereas a negative value indicates a lower percentage of the OTU in the downstream biofilm. Only variations N2\% (positive or negative) were considered.

\section{Results and discussion}

\subsection{Pharmaceutical occurrence in biofilms exposed to the discharge from WWTPs}

The analysis of pharmaceuticals shows that five to 11 compounds (among the 12 analysed) were quantified in the 12 biofilms studied (Fig. 1). This finding confirms the ability of biofilms to sorb pharmaceutical compounds present in natural waters. A recent study performed on a Spanish river also observed the occurrence of three to six pharmaceuticals (among the 44 analysed) in the biofilms affected by effluent from WWTPs (Huerta et al., 2016). In our study, all the pharmaceuticals (except MTN-0\% of detection frequency) were detected in N50\% of the biofilms, with the exception of IOX (31\% of detection frequency). It is worth noting that pharmaceuticals with different types and degrees of ionization were found in the biofilms. Thus, many negatively charged (LVF + OFLO, SMX, DCF), uncharged (CBZ), and positively charged pharmaceuticals (PROP) were detected in all of the biofilm samples (nb. Considering the ionization of their functional groups at typical $\mathrm{pHs}$ of the Vienne river 78 and the acid dissociation constant [pKa] values reported in Table 2). Furthermore, some of these compounds (e.g., PROP, CBZ, and DCF) present high octanol-water partition coefficient (log Kow) values ranging from 2.5 to 4.4 (Table 2) whereas the other (e.g., LCF + OFLO and SMX) present log Kow values below one (i.e., log Kow indicates the hydrophilic character of a molecule, higher is the value higher is the hydrophobicity). These findings, which indicate the chemical properties of pharmaceuticals (pKa, log Kow), are not the determining factors for the fixation of these compounds by biofilms.

It is remarkable to note that the highest detection frequencies were observed for "the most classical" pharmaceuticals (i.e., CBZ, DCF, PROP, and SMX - Fig. 1), which could be attributed to their large distribution and resistance to degradation. Generally, DCF (a NSAID) is one of the most common pharmaceuticals reported because it can be purchased without a medical prescription. The percentage of this drug's removal is generally high (Jelić et al., 2012); however, it is still detected in rivers downstream from WWTPs due to its very high usage in human medicine. DCF is usually detected at very high concentrations in natural waters worldwide (from ng/L to $\mu \mathrm{g} / \mathrm{L}$; Kasprzyk-Hordern et al., 2008; Scheurell et al., 2009). In the present work, DCF was also detected in $100 \%$ of the biofilms (with concentrations up to $190 \mathrm{ng} / \mathrm{g}$ ) collected immediately downstream from the WWTPs (Fig. 1). It is worth noting that DCF is also the most concentrated pharmaceutical measured in Spanish biofilms, with a maximum concentration of $100 \mathrm{ng} / \mathrm{g}$ immediately downstream from a WWTP (Huerta et al., 2016). 
CBZ, the other most prominent pharmaceutical almost always found in natural waters (Petrovic et al., 2009; Fernández et al., 2010), was also found in $100 \%$ of the Vienne River biofilms. The maximum concentration of CBZ reached $583.5 \mathrm{ng} / \mathrm{g}$ of biofilm. One metabolite of CBZ (e-CBZ) was also observed in more than half of the biofilms, confirming the affinity of the Vienne River biofilms for CBZ-like molecules. On the contrary, Huerta et al. (2016) never observed CBZ in the Segre River biofilm samples despite its occurrence in water ( 15 to $39 \mathrm{ng} / \mathrm{L}$ ). Furthermore, CBZ is also known for having a low distribution coefficient with environmental matrices, such as river sediments (Scheytt et al., 2005), which indicates the low sorption of this molecule. Nevertheless, it should be noted that CBZ is a prescription drug with a long history of clinical usage (Petrovic et al., 2009) and is almost continually present at low levels in natural waters.

In the present work, the highest concentration of pharmaceuticals in biofilms was observed for PROP, another prescription drug (maximal concentration: $965 \mathrm{ng} / \mathrm{g}$; detection frequency: 100\%). The presence of this compound is coherent since beta-blockers are ubiquitous worldwide in the discharge of WWTPs and is commonly quantified in surface water (nb. PROP was found in $\mathrm{N} 80 \%$ of water samples collected in British and Spanish rivers-Fernández et al., 2010; Kasprzyk-Hordern et al., 2008). Ashton et al. (2004) detected PROP in water samples collected downstream from a WWTP in the United Kingdom at a mean concentration of $41 \mathrm{ng} / \mathrm{L}$ (with a maximum of $215 \mathrm{ng} / \mathrm{L}$ ). Its presence in biofilms is coherent with its reactivity since PROP is also known to be easily sorbed into sediments ( $29 \mathrm{ng} / \mathrm{g}$ in German river sediments-Ramil et al., 2010). Nevertheless, the study conducted by Huerta et al. (2016) never observed PROP in the biofilms or the water samples collected in the River Segre (Spain).

Three antibiotics (LVF + OFLO, SMX, and TMP) were also found in N70\% of the biofilms with concentrations ranging from 1.1 to $276 \mathrm{ng} / \mathrm{g}$. LVF+OFLO and SMX were found in all the biofilms. The maximum concentration was found for the antibiotics LVF + OFLO $(276 \mathrm{ng} / \mathrm{g})$ and SMX $(20.1 \mathrm{ng} / \mathrm{g})$ at 'Chatel'. TMP was less frequently detected (75\%) in the biofilms at concentrations up to $10.4 \mathrm{ng} / \mathrm{g}$. It should be noted that the presence of these antibiotics was not observed in the biofilms studied by Huerta et al. (2016). Nevertheless, the affinity of certain antibiotics for environmental components was not surprising since Kimand Carlson (2007) have found $1.9 \mathrm{ng} / \mathrm{g}$ of SMX in sediments in the United States. Furthermore, numerous studies confirmed the substantial presence of antibiotics in the environment, due to their widespread consumption in human and veterinary medicines. Gros et al. (2007) found SMX and TMP in all of the samples analysed at seven Spanish WWTPs and at considerable loads, followed by the fluoroquinolone OFLO. The results of a study in six Italian WWTPs (Castiglioni et al., 2006) indicated high inputs of antibiotics (SMX, OFLO, and ciprofloxacin) in rivers. The notable fixation of antibiotics on environmental particles may be explained by surface complexation/sorption reactions (Figueroa and Mackay, 2005; Gu and Karthikeyan, 2005).

The presence of an iodinated X-ray contrast agent (IOX) was observed in four of the 12 biofilms sampled ('StLeo', 'LLC', 'Chatel', and 'Chauv'). It is worth noting that only one of these sites ('Chatel') is exposed to a WWTP that treats hospital sewage waters. Normally X-ray contrast media are given to patients in radiology departments and then excreted in the appropriate ward; however, $30 \%$ of patients (treated as outpatients) excreted it at home (Kümmerer, 2004). Thus, Clara et al. (2005) have detected significant traces of X-ray contrast media in the influent of a WWTP receiving hospital discharge, whereas concentrations are below the detection limit in WWTPs without a hospital. The low occurrence of IOX in biofilms may also be explained by its chemical properties. IOX is not a high hydrophobic compound ( $\log$ Kow $=-3.0-$ Table 2$)$ and is generally poorly fixed by environmental matrices, such as sediments and soils (Sacher et al., 2001). 


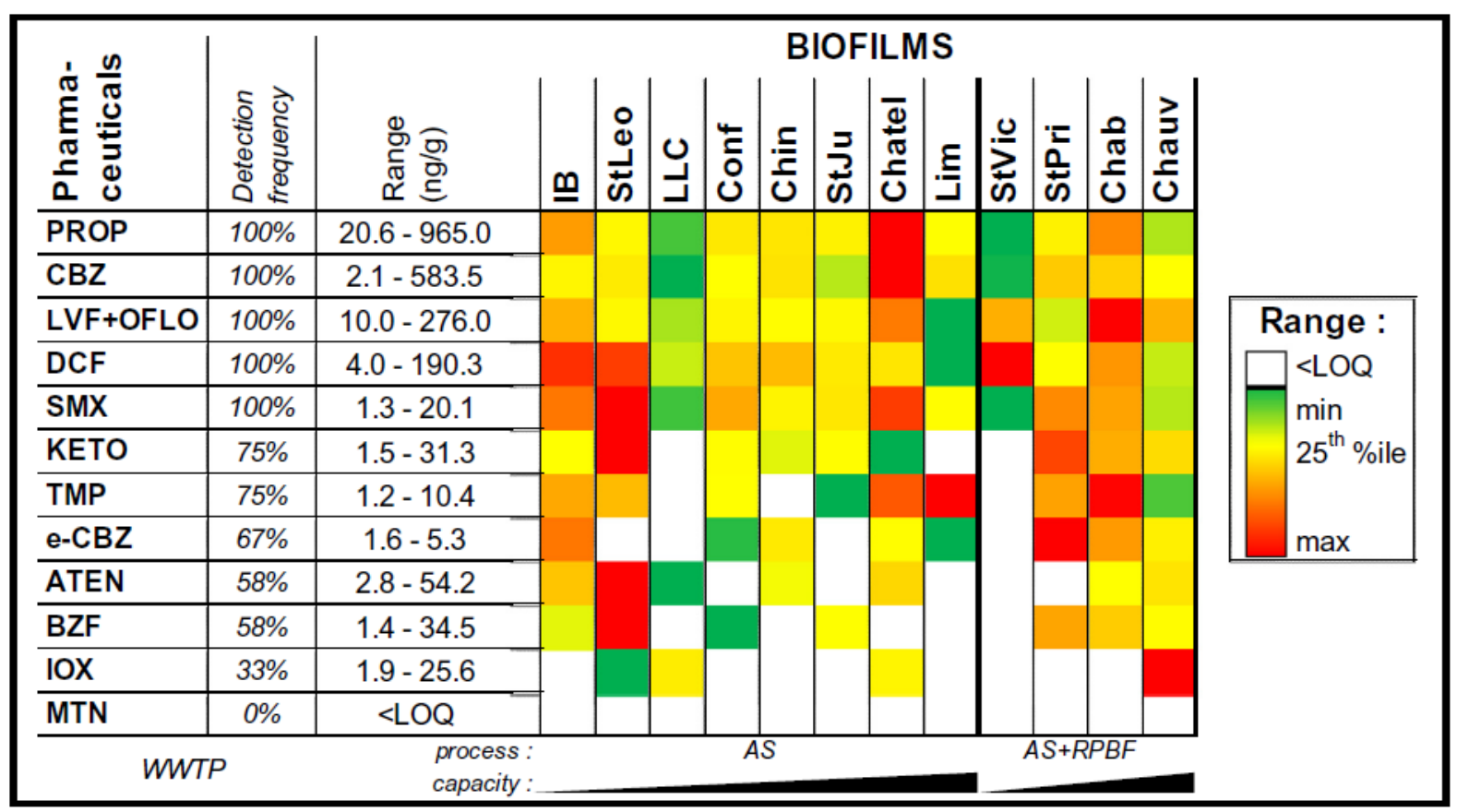

Fig. 1. Distribution of the pharmaceutical concentrations of the biofilms (in $\mathrm{ng} / \mathrm{g}$ of dry biofilm) collected immediately downstream from the WWTP outfall (LOQ: limit of quantification - the concentration of each pharmaceutical at each site is presented with a coloured square. For each pharmaceutical, the green square corresponds to the lowest concentration while the red square marks the maximum concentration. A yellow square corresponds to a concentration around the 25th percentile); AS: activated sludge process; AS + RPBF: activated sludge followed by a reed-planted bed filter. (nb. values used to represent the heatmap are presented in Table SI4).

\subsection{Biofilm's contamination pattern regarding the characteristics of WWTPs}

Fig. 1 shows a heat map of the pharmaceutical concentrations in the biofilms regarding the type and the capacity of the WWTP. This broad view of the contamination shows many differences between each biofilm, meaning the biofilm contamination is site-dependent. Thus, regarding the results obtained for an activated sludge WWTP, the heat map shows that the biofilms collected at 'StLeo' and 'Chatel' were contaminated by different pharmaceuticals at high concentrations (KETO, DCF, SMX, BZF, and ATEN at 'StLeo' and CBZ, PROP, and SMX at 'Chatel') (Fig. 1). The biofilms from 'IB' were also significantly contaminated but contain fewer molecules at high concentrations. Significant differences were also observed for biofilms exposed to AS + RPBFWWTP ('StVic', 'StPri', 'Chab', and 'Chauv'). It is worth noting that none of the processes (AS or AS + RPBF) causes higher pollution in the biofilms than the other. Thus, the 'LLC' (AS) and 'StVic' (AS + RPBF) biofilms present a low contamination (Fig. 1) whereas 'Chatel' (AS) and 'Chab' (AS + RPBF) present a high contamination.

Five of theWWTPs ('StLeo', 'StJu', 'Lim', 'StVic', and 'StPri') operate at effective daily flow rates that are higher than their capacity (Table 1). The effective daily operation conditions are generally known to be an important parameter influencing the quality of the discharge from WWTPs. However, the present results show that such configurations do not favour higher contamination in the biofilms. Thus 'Lim' and 'StVic' are not considered hot spots for biofilm contamination, despite operating above their nominal capacities. Likewise, the 'IB' and 'Chab' WWTPs operate under their nominal capacity but lead to a high contamination of the biofilms (Fig. 1). It is also worth noting that these two WWTPs correspond to small cities (2250 PE and $3300 \mathrm{PE}$ for 'IB' and 'Chab' respectively-Table 1). Furthermore, different contamination patterns were observed for biofilms at the biggest WWTPs. Thus, the biofilm collected downstream from 'Chatel' (92,833 PE) was one of the most contaminated, whereas the biofilm collected downstream from 'Lim' (285,000 PE) presented low diversity of molecules and low concentrations.

The potential for the natural dilution of the river-represented by the flow of the WWTP discharge divided by the flow of the river-seems to be without incidence for the contamination levels of the 
biofilms located downstream from the WWTPs. Therefore, the observed dilution rates reported in Table SI-1 indicate a high dilution potential at 'IB' and 'Chab', whereas the biofilms present significant amounts of many pharmaceuticals. However, the contamination level of the biofilms collected at 'Lim' and 'StJu' was lower despite very low dilution rates ( $1 / 25 \mathrm{e}$ and $1 / 375 \mathrm{e}$, respectively). This parameter seems not to be the main explanatory variable for the biofilm contamination.

All of these findings suggest that no evident relationship exists between the distribution of pharmaceuticals in biofilms and the specificities of the WWTPs considered in the present work (process and capacity). Nevertheless, a statistical analysis by multidimensional scaling (MDS) was performed in order to support this finding. The results of the MDS validated the absence of the relationship between the process (type or capacity) and the contamination of the biofilms (nb. the figure is presented in the supporting information, Fig. SI-2).

\subsection{Influence of source-distance on the river biofilm contamination}

The EFs in the pharmaceuticals were determined from the concentrations found in the biofilms collected upstream and downstream from each WWTP. Fig. 2 presents the individual EF calculated for each pharmaceuticals (nb. the results are presented only for sites where biofilms were collected at $0 \mathrm{~m}$ and $10 \mathrm{~m}$. The EF obtained for the other sites 'Conf', 'StJu', 'Lim', 'StVic', 'StPri', and 'Chab' are presented in the supporting information, Figs. SI-3 and SI-4). Thus, for the biofilms collected at $0 \mathrm{~m}$, an overall positive EF was observed for almost all molecules and almost all sampling sites, which supports the strong influence of the neighbouring WWTP on the biofilm contamination (Fig. 2). It is also worth noting that several molecules (DCF, SMX, and KETO) were found at significant concentrations in the $0 \mathrm{~m}$ biofilm whereas they were frequently not detected in the upstream biofilms (see the dark symbol in Fig. 2). In some cases, such as at 'LLC', the EFs of CBZ, LVF + OFLO, and TMP were negative, which suggests that the biofilm exposed to the WWTP was less exposed to these compounds than its corresponding upstream biofilm.

The EF obtained for the ' $10 \mathrm{~m}$ ' biofilms indicate that the influence of the release of the WWTPs is related to the distance. Nevertheless, the ' $10 \mathrm{~m}$ ' biofilms presented mostly lower (or negative) enrichment factors compared to the ' $0 \mathrm{~m}$ ' biofilms. Thus, the EFs for PROP and CBZ exhibited a significant decrease at $10 \mathrm{~m}$ in almost the biofilms. It is worth noting that this decrease depends more or less on the site considered. Thus, the EFs are very close between the ' $0 \mathrm{~m}$ ' and the ' $10 \mathrm{~m}$ ' biofilms collected at 'StLeo'. This finding suggests that the influence of the WWTPs is as important for the two biofilms. On the contrary, the difference between the ' $0 \mathrm{~m}$ ' and ' $10 \mathrm{~m}$ ' biofilms collected at 'IB' suggests that the influence is already reduced at $10 \mathrm{~m}$.

The series of biofilms collected at 'Chatel' shows that the influence of WWTPs can be perceptible up to $100 \mathrm{~m}$. Nevertheless, the values of enrichment are close to those observed at $10 \mathrm{mand}$ lower than the enrichment found at $0 \mathrm{~m}$. The results obtained at 'Chatel' also show that the evolution of the EFs at various distances can be different according to the molecules. Thus, significant decreases in the EFs were observed for PROP, CBZ, and SMX, whereas minor differences were observed for LVF + OFLO and DCF.

Other studies have reported a decrease in contamination the greater the distance from the source of the discharge. Indeed, da Silva et al. (2011) found higher concentrations of ranitidine (an anti-acid) in river sediments $(4.7-25.0 \mathrm{ng} / \mathrm{g}$ ) collected downstream from WWTPs compared to other sampling points located a few kilometres downstream $(\sim 1 \mathrm{ng} / \mathrm{g})$. This difference of exposition can be associated with the dilution phenomena (Ellis, 2006; Gabet-Giraud et al., 2014) and can explain the obtained profiles. Huerta et al. (2016) have also shown the impact of distance on the distribution and total concentration of pharmaceuticals in natural biofilms up to $5 \mathrm{~km}$. The present study shows that the distance from the outfall affects both the pharmaceutical distribution and concentration found in the biofilms. This finding shows that both the dilution effect and the physic-chemical effects (i.e., sorption/desorption, competition, and interactions with other compounds or organic matter) cause the pharmaceutical concentrations to decrease in the biofilms and probably in water. 

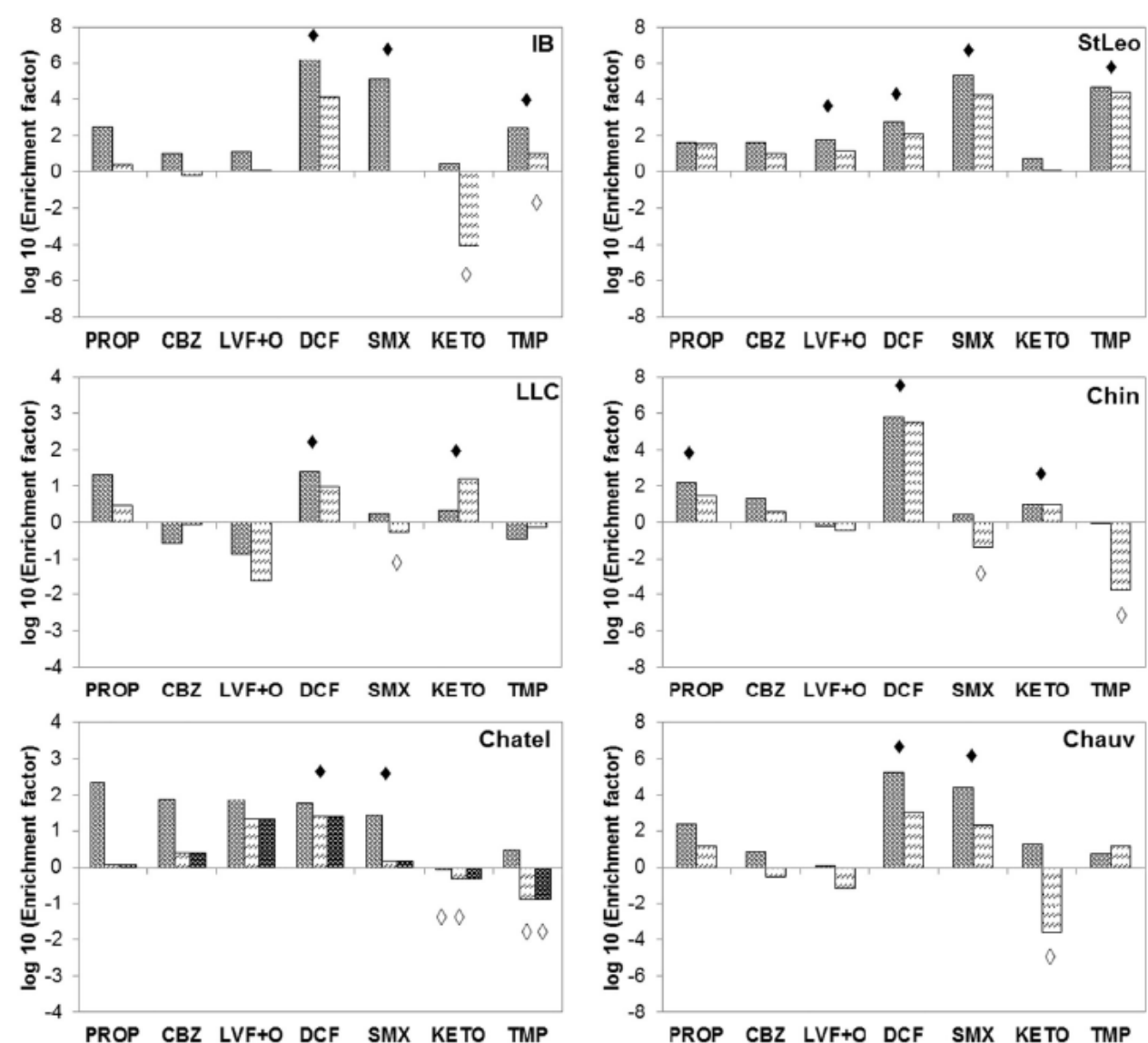

回'0 m' biofilm घ'10 m' biofilm

: '100 m' biofilm

Fig. 2. Pharmaceuticals enrichment factor between the 'upstream' biofilms and the biofilms collected 0,10 and 100mdownstreamfromtheWWTP of 'IB', 'StLeo', 'LLC', 'Chin', 'Chatel', and 'Chauv'. \$: 'upstream' biofilm concentration equal to the LOQ; $\diamond$ : 'downstream' biofilm concentration equal to the LOQ. *: only for 'Chatel'. (ATEN, BZF, e-CBZ, MTN and IOX not considered-detection frequencies lower than 70\%; It should be noted that concentrations in the upstream biofilms used for the enrichment factor were below $10 \mathrm{ng} / \mathrm{g}$ for all pharmaceuticals).

\subsection{Incidence of the contamination on biofilms bacterial communities}

A broad characterization of the bacterial communities was performed to determine the modification of the biofilm bacterial diversity induced by the discharge of WWTPs. The EFs were analysed for the major individuals composing the biofilms (Fig. 3).

The EFs highlight the changes that occur in the bacterial diversity of biofilms that are exposed to the discharge of WWTPs. Thus, biofilms contain some microorganisms that are typically released by WWTPs. Indeed, members of the Clostridiales (Clostridiaceae and Peptostreptococcaceae) increase in almost all the biofilms exposed to ASWWTP, with the exception of 'Lim' (that is marked by a high increase in Exiguobacterium). Clostridiales microbial communities are frequently reported across differentWWTPs as an indicator of human faecal pollution (McLellan et al., 2010; Wéry et al., 2010). At 'Chatel' the discharge favours the presence of Actinomycetales communities, generally depicted as environmental or commensal bacteria. Other sewage-indicator microorganisms were observed at 'StJu' and 'Conf' where there was an increase in communities involved in nitrogen removal (Nitrospira and Rhizobiales).

The study of the bacterial diversity also highlights the impact of the discharge ofWWTPs on themembers of cyanobacteria. Thus, a decrease in several cyanobacteria (e.g., Leptolyngbya, Phormidium, and Synechococcus) was observed in most biofilms (nb. only Xenococcaceae increased significantly at 'Chin'). Despite the lack of knowledge about the ecology of all the species, the characteristics of cyanobacteria generally provide some advantages for eutrophic environments, such as the adaptability to low light and better use of dissolved nutriments (Chorus and Batram, 1999). 


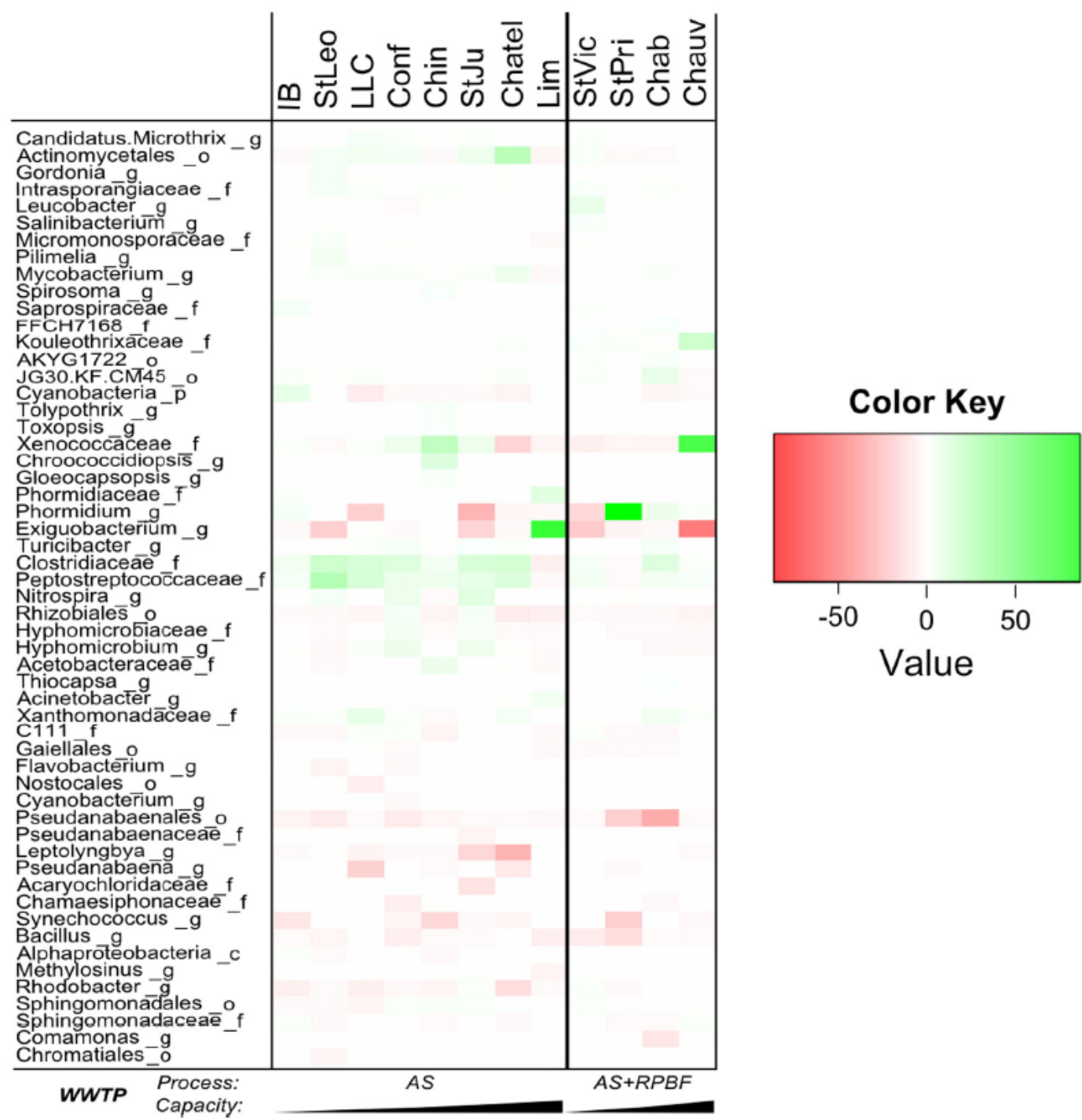

Fig. 3. EFs of the OTU in the '0m' biofilms. Green or red colours highlight an increase or a decrease, respectively, of the given community. AS: activated sludge process; AS+RPBF: activated sludge followed by a reed-planted bed filter.

It is worth noting that a reduction of cyanobacteria (e.g., Pseudoanabenales and Synechococcus)was also observed for biofilms exposed to AS + RPBFWWTP discharge. Nevertheless, these biofilms exhibited local increases in certain communities, such as cyanobacteria (Xenococcaceae at 'Chauv', and Phormidium at 'StPri') and sewage indicators (Clostridiaceae at 'Chab').

The present results suggest that the discharge is unfavourable to the proliferation of several cyanobacteria, as well as to other communities (e.g., alphaproteobacteria such as Rhodobacter or bacteria such as Bacillus). Several hypotheses may explain these differences. Thus, an increase in organic matter (due to discharge from WWTPs) may result in the reduction of water transparency (increased turbidity and suspended solids) and lead to the stress of photosynthetic organisms, such as cyanobacteria. It may also be proposed that recalcitrant high molecular-weight organic matter may act as an inhibitor of microbial metabolism through occlusion of the surface of the biofilm (Freeman and Lock, 1992). The decrease of some communities could also result from the death or emigration of sensitive organisms and the proliferation of tolerant organisms to the discharge for theWWTPs, or the competition with bacteria coming from the WWTPs. On the contrary, an increase of nutrients may have stimulated the abundance of certain species.

The characteristics of WWTPs (i.e., type, nominal, and effective capacity) showed no evident relationships with these different modifications of bacterial communities. This finding was confirmed by a multidimensional statistical analysis. Thus, an nMDS was computed based on the enrichment factor 
calculated for the OTU. A two-dimensional projection of the Bray-Curtis index similarity matrix allowed for the visualization of the similarity between each biofilm bacterial community (i.e., the distance between circles).

According to the low percentage of similarities given by the Bray-Curtis index, the overall composition of the bacterial communities from the biofilms was different (Fig. 4). In addition, the clustering of the different sites does not underline any specific effect of the size or the type of process on the composition of the biofilm bacterial communities. It should be noted that the clustering analysis is based on the genus level; however, the same result was obtained when performed at the OTU level.

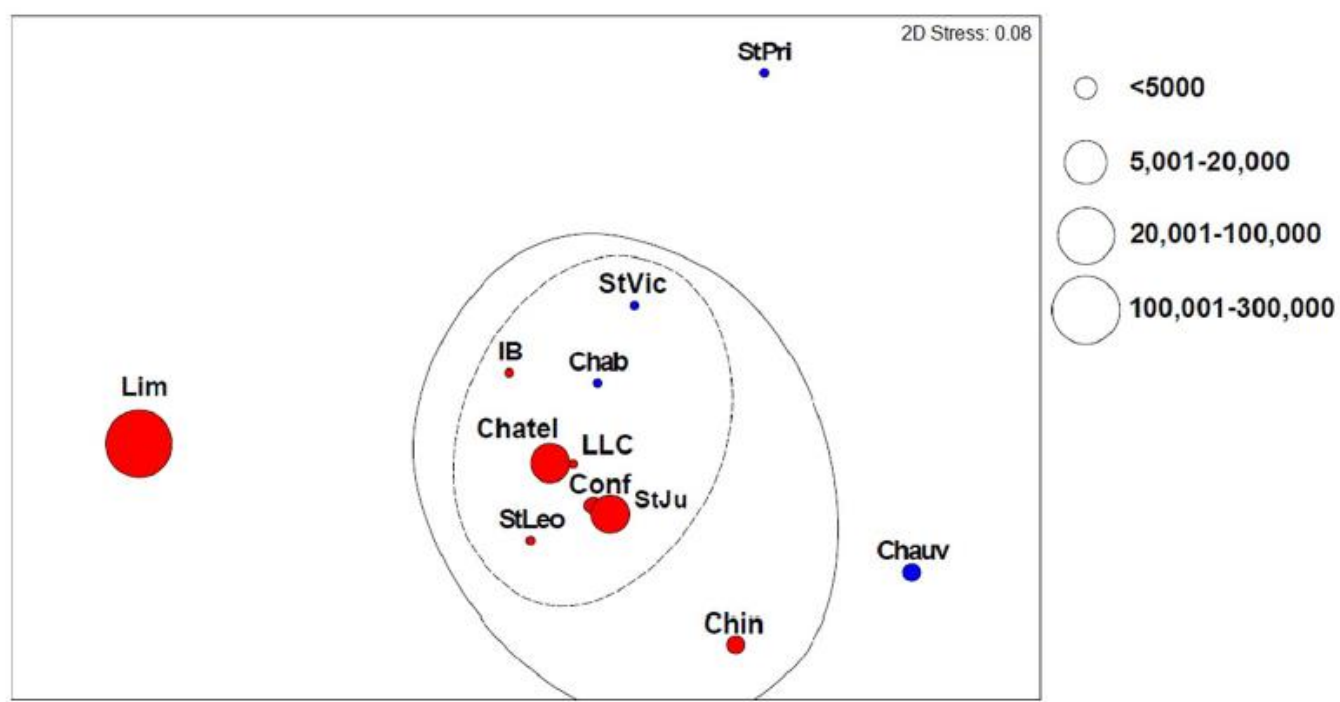

Fig. 4. A 2D-nMDSmap based on the bacterial community composition of the biofilms collected immediately downstream from WWTP outfalls. Red circle: Activated sludge process; blue circle: AS+ RPBF. Plain and dashed lines represent the differing percentages of similarities (10\% and 20\% similarities, respectively).

\subsection{Effect of contamination on the abundance of resistance integrons}

The abundance of resistance genes in the biofilms was assessed by the presence of Class 1, 2, and 3 integrons (Fig. 5). The results indicate a significant enrichment of Class 1 integrons caused by the discharge of WWTPs. Thus, the EFs present an increase of three- to 31-fold for almost all biofilms. This finding is supported by the high number of normalized copies of Class 1 integrons found in the biofilms, especially at 'StLeo', 'StVic', and 'Chab' ( $0.08,0.09$, and 0.15 , respectively). The values observed for these three sites and the others are in the range of the normalized copies found in environments impacted by anthropic activities (Ma et al., 2011; Diehl and LaPara, 2010; Stalder et al., 2013; Stalder et al., 2014). Indeed, the enrichment of Class 1 integrons was frequently reported at sites polluted by sewage water (Figueira et al., 2011; Rosewarne et al., 2010; LaPara et al., 2011; Uyaguari et al., 2011). Only two sites ('IB' and 'Lim') presented no enrichment in Class 1 integrons, which suggests no impact of the discharge of WWTPs on the biofilms. In addition, the measurements of Class 1 integrons performed on the upstream biofilms reveal the presence of 0.0006 to 0.008 copies of Class 1 integrons (except at 'LLC' [0.012]) (data is provided in the supporting information, Table SI-5). This background level, apart from the exposure source, is coherent with the natural presence of the Class 1 integrons found in non-impacted anthropogenic areas, such as river/lake water, sediment, biofilm, and soil (Wright et al., 2008, LaPara et al., 2011; Gaze et al., 2011, Amos et al. 2015).

Some of the biofilms analysed were also characterized by an enrichment of Class 3 integrons; however, the results were different from the Class 1 integrons. The normalized copy number was lower (b0.036) than that of the Class 1 integrons and the measurements performed on the upstream biofilms revealed the limited presence of these integrons, which suggests their low abundance in the Vienne River (data provided in Table SI-5). Only two sites presented significantly high EFs ('Chin' and 'Chatel', 0.36 and 0.42 , respectively). All the other sites presented no enrichment of the Class 3 integrons. This finding suggests no general incidence of the discharge of WWTPs in this class of integrons, but rather a local impact. Class 3 integrons are still poorly described in the literature but they have been observed in various clinical and environmental strains (Simo Tchuinte et al., 2016). It should be noted that Class 2 
integrons were not detected in the samples studied. However, this result was coherent with the low abundance reported in the natural environment (Stalder et al., 2012).
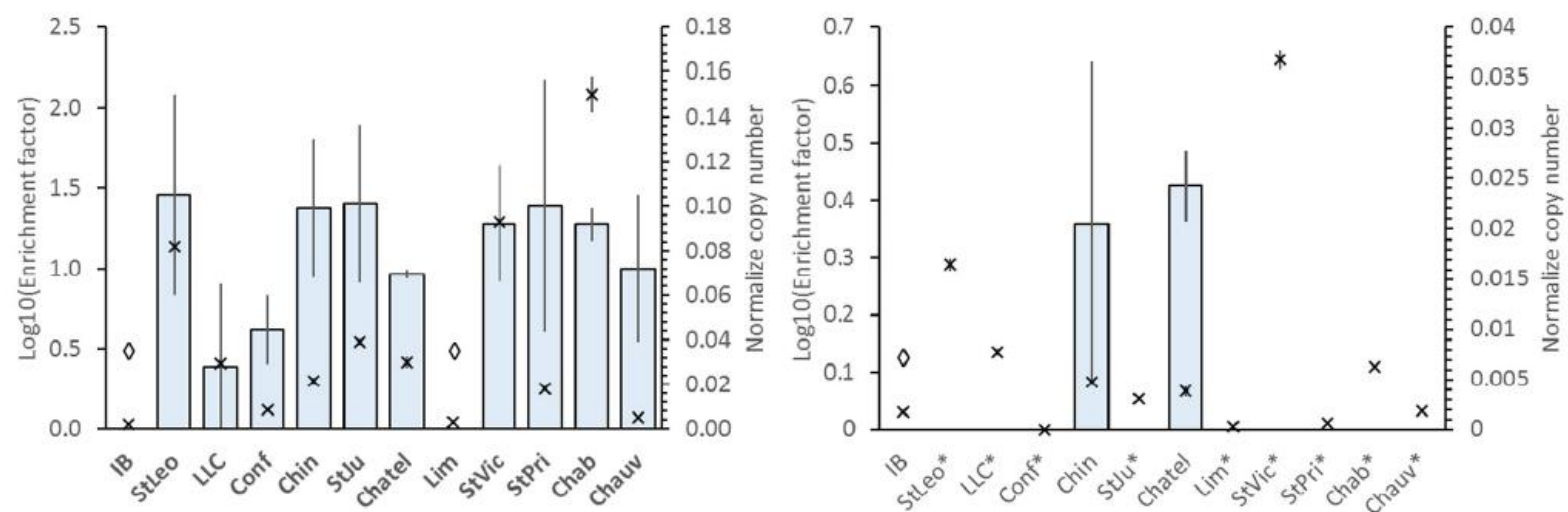

Fig. 5. Class 1 integrons (left) and Class 3 integrons (right) enrichment factor between the upstream biofilms and the ' $0 \mathrm{~m}$ ' biofilms (histograms) and normalized number of integrons copies in the ' $0 \mathrm{~m}$ ' biofilms (crosses). $\diamond$ : negative enrichment observed; *: integrons concentrations were not quantifiable in the upstream biofilm.

Many studies agree that the chronic exposure to antibiotics favours the presence of resistance genes in microbial communities (Balcázar et al., 2015; Martinez, 2009). It is worthwhile to underline that Class 1 integrons are often associated with gene cassettes, which confers resistance to sulfonamide (sul1) and trimethoprim (dfr). Concerning the quinolone antibiotic LVF and OFLO, Class 1 integrons have been associated with the resistance gene (qnr). Thus, some correlations are frequently observed between the abundance in resistance genes and the concentration of antibiotics (Gao et al., 2012). In the present work, no direct relation was found between these two types of data. Despite the high concentration of LVF + OFLO and TMP matching with the high enrichment of Class 1 integrons observed at 'Chab' and 'Chatel', lower concentrations were observed at 'StVic' where a high enrichment of Class 1 integrons was observed. The absence of a correlation may be explained by the ability of integrons to acquire several antibiotic resistance genes (Khan et al., 2013), but also by often being associated with plasmids vectoring other resistance genes. Thus, the resistance may be associated with the presence of other molecules (not analysed in the present work). Nevertheless, it should be noted that some antibiotics were found in all the biofilms, which suggests the possible exposure of the biofilm bacteria to these compounds.

\section{Conclusion}

The present work provides an overview of the presence of pharmaceutical compounds in river biofilms exposed to the discharge from WWTPs. The results highlight the presence, in all the biofilms, of several compounds (5 to 11 on the 12 studied) that are among the most classical pharmaceuticals occurring in natural waters (CBZ, DCF, PROP, SMX). The presence of many antibiotics at concentrations up to 276 $\mathrm{ng} / \mathrm{g}$ was also highlighted, which suggests favourable conditions for the maintenance of antibiotic resistance. Furthermore, exposure to the discharge from WWTPs also increases the presence of Class 1 integrons in almost all the biofilms (three- to 31-fold). The effect on Class 3 integrons was less significant.

The study of contamination patterns reveals that the contamination of biofilms is site-dependent. In addition, no relationship was found between the distribution of pharmaceuticals in the biofilms and the specificities of the WWTPs (i.e., process and operating daily flow rate). Nevertheless, the series of biofilms collected at $0 \mathrm{~m}, 10 \mathrm{~m}$, and $100 \mathrm{~m}$ shows a decrease in contamination relative to the distance from the discharge point. However, this decrease depends on the molecule considered.

All of these results confirm that discharge from WWTPs has an effect on the contamination of biofilms through the fixation of pharmaceuticals and the development of antibiotic resistance makers. The results also confirm that biofilm is a useful tool to evaluate the impact of anthropic activities on aquatic environments. 


\section{Acknowledgments}

This study was financially supported by the Centre National de la Recherche Scientifique (CNRS), the Region Poitou-Charentes and the Poitou-CharentesWater Research Programm (CPER\#1).

\section{References}

Aminov, R.I., 2011. Horizontal gene exchange in environmental microbiota. Front. Microbiol. 2:158. http://dx.doi.org/10.3389/fmicb.2011.00158. Aminov, R.I.,Mackie, R.I., 2007. Evolution and ecology of antibiotic resistance genes. FEMS Microbiol. Lett. 271:147-161. http://dx.doi.org/10.1111/j.1574-6968.2007.00757.x.

Amos, G., Gozzard, E., Carter, C.E., Mead, A., Bowes, M.J., Hawkey, P.M., Zhang, L., Singer, A.C., Gaze,W.H., Wellington, E., 2015. Validated predictive modelling of the environmental resistome. ISME J. 9:1467-1476. http://dx.doi.org/10.1038/ismej.2014.237.

Ashton, D., Hilton, M., Thomas, K.V., 2004. Investigating the environmental transport of human pharmaceuticals to streams in the United Kingdom. Sci. Total Environ. 333: 167-184. http://dx.doi.org/10.1016/j.scitotenv.2004.04.062.

Baker, D.R., Kasprzyk-Hordern, B., 2013. Spatial and temporal occurrence of pharmaceuticals and illicit drugs in the aqueous environment and during wastewater treatment: new developments. Sci. Total Environ. 454-455:442-456. http://dx.doi.org/10.1016/j.scitotenv.2013.03.043.

Balcázar, J.L., Subirats, J., Borrego, C.M., 2015. The role of biofilms as environmental reservoirs of antibiotic resistance. Front. Microbiol. 6. http://dx.doi.org/10.3389/fmicb.2015.01216

Baquero, F., Martínez, J.-L., Cantón, R., 2008. Antibiotics and antibiotic resistance in water environments. Curr. Opin. Biotechnol. 19:260-265 Energy Biotechnology/Environmental Biotechnology. 10.1016/j.copbio.2008.05.006.

Barraud, O., Baclet, M.C., Denis, F., Ploy, M.C., 2010. Quantitative multiplex real-time PCR for detecting class 1, 2 and 3 integrons. J. Antimicrob. Chemother. 65:1642-1645. http://dx.doi.org/10.1093/jac/dkq167.

Bartelt-Hunt, S.L., Snow, D.D., Damon, T., Shockley, J., Hoagland, K., 2009. The occurrence of illicit and therapeutic pharmaceuticals in wastewater effluent and surface waters in Nebraska. Environ. Pollut. 157:786-791. http://dx.doi.org/10.1016/j.envpol.2008.11.025.

Batt, A.L., Bruce, I.B., Aga, D.S., 2006. Evaluating the vulnerability of surface waters to antibiotic contamination from varying wastewater treatment plant discharges. Environ. Pollut. 142:295-302. http://dx.doi.org/10.1016/j.envpol.2005.10.010.

Berlioz-Barbier, A., Buleté, A., Faburé, J., Garric, J., Cren-Olivé, C., Vulliet, E., 2014. Multiresidue analysis of emerging pollutants in benthic invertebrates by modified microquick- easy-cheap-efficient-rugged-safe extraction and nanoliquid chromatography-nanospray-tandem mass spectrometry analysis. J. Chromatogr. A 1367:16-32. http://dx.doi.org/10.1016/j.chroma.2014.09.044.

Boxall, A., Bauckhaus, T., Brooks, B.W., Gouy, D., Hickman, S., Kidd, K., Metcalfe, C.,

Netherton, M., Parrott, J., Smith, E., Straub, J.O., Weeks, J., 2008. Knowledge and Need Assessment on Pharmaceutical Products in Environmental Waters (KNAPPE) (Report on Environmental Impact and Health Effects of Pharmaceutical Products).

Burger, J., Gochfeld, M., 2001. On developing bioindicators for human and ecological health. Environ. Monit. Assess. 66:23-46. http://dx.doi.org/10.1023/A: 1026476030728.

Caporaso, J.G., Kuczynski, J., Stombaugh, J., Bittinger, K., Bushman, F.D., Costello, E.K., Fierer, N., Peña, A.G., Goodrich, J.K., Gordon, J.I., Huttley, G.A., Kelley, S.T., Knights, D., Koenig, J.E., Ley, R.E., Lozupone, C.A., McDonald, D., Muegge, B.D., Pirrung, M., Reeder, J., Sevinsky, J.R., Turnbaugh, P.J., Walters, W.A., Widmann, J., Yatsunenko, T., Zaneveld, J., Knight, R., 2010. QIIME allows analysis of high-throughput community sequencing data. Nat. Methods 7:335-336. http://dx.doi.org/10.1038/nmeth.f.303.

Castiglioni, S., Bagnati, R., Fanelli, R., Pomati, F., Calamari, D., Zuccato, E., 2006. Removal of pharmaceuticals in sewage treatment plants in Italy. Environ. Sci. Technol. 40: 357-363. http://dx.doi.org/10.1021/es050991m.

Chorus, I., Batram, J., 1999. Toxic Cyanobacteria in Water: a Guide to their Public Health Consequences, Monitoring and Management, E \& FN. Spon. ed. WHO, London.

Clara, M., Strenn, B., Gans, O., Martinez, E., Kreuzinger, N., Kroiss, H., 2005. Removal of selected pharmaceuticals, fragrances and endocrine disrupting compounds in a membrane bioreactor and conventional wastewater treatment plants. Water Res. 39: 4797-4807. http://dx.doi.org/10.1016/j. watres.2005.09.015.

Demarre, G., Frumerie, C., Gopaul, D.N.,Mazel, D., 2007. Identification of key structural determinants of the IntI1 integron integrase that influence attC $\times$ attI1 recombination efficiency. Nucleic Acids Res. 35:6475-6489. http://dx.doi.org/10.1093/nar/gkm709.

Diehl, D.L., LaPara, T.M., 2010. Effect of temperature on the fate of genes encoding tetracycline resistance and the integrase of class 1 integrons within anaerobic and aerobic digesters treating municipal wastewater solids. Environ. Sci. Technol. 44:9128-9133. http://dx.doi.org/10.1021/es102765a.

Directive 2000/60/EC, 2000. European Directive Establishing a Framework for Community Action in the Field of Water Policy-23th October 2000.

Directive 91/271/EEC, 1991. European Directive Concerning Urban Waste-water Treatment-21 May 1991.

Drury, B., Rosi-Marshall, E., Kelly, J.J., 2013.Wastewater treatment effluent reduces the abundance and diversity of benthic bacterial communities in urban and suburban rivers. Appl. Environ.Microbiol. 79:1897-1905. http://dx.doi.org/10.1128/AEM.03527-12.

Ellis, J.B., 2006. Pharmaceutical and personal care products (PPCPs) in urban receiving

waters. Environ. Pollut. 144:184-189 Soil and Sediment Remediation (SSR) Soil and Sediment Remediation (SSR). 10.1016/j.envpol.2005.12.018

Vienne, E.P.T.B., 2011. Le tableau de bord du bassin de la Vienne. EPTB (Etablissement Public du bassin de la Vienne). http://www.eptb-vienne.fr/

Tableau-de-bord-du-Bassin.html.

Fernández, C., González-Doncel, M., Pro, J., Carbonell, G., Tarazona, J.V., 2010. Occurrence of pharmaceutically active compounds in surface waters of the henaresjarama-tajo river system (Madrid, Spain) and a potential risk characterization. Sci. Total Environ. 408:543-551. http://dx.doi.org/10.1016/j.scitotenv.2009.10.009.

Figueira, V., Serra, E., Manaia, C.M., 2011. Differential patterns of antimicrobial resistance in population subsets of Escherichia coli isolated from waste- and surface waters. Sci. Total Environ. 409:1017-1023. http://dx.doi.org/10.1016/j.scitotenv.2010.12.011.

Figueroa, R.A., MacKay, A.A., 2005. Sorption of oxytetracycline to iron oxides and iron oxide-rich soils. Environ. Sci. Technol. 39 (17):6664-6671. http://dx.doi.org/10.1021/es0480441.

Freeman, C., Lock, M.A., 1992. Recalcitrant high-molecular-weightmaterial, an inhibitor of microbial metabolism in river biofilms. Appl. Environ. Microbiol. 58, 2030-2033

Gabet-Giraud, V., Miège, C., Jacquet, R., Coquery, M., 2014. Impact of wastewater treatment plants on receiving surface waters and a tentative risk evaluation: the case of estrogens and beta blockers. Environ. Sci. Pollut. Res. 21:1708-1722. http://dx.doi.org/10.1007/s11356-013-2037-7.

Gagné, F., Blaise, C., 2004. Effects of pharmaceuticals on aquatic biota-a review. Curr. Top. Toxicol. 1, 73-86.

Gao, P., Munir, M., Xagoraraki, I., 2012. Correlation of tetracycline and sulphonamide antibiotics with corresponding resistance genes and resistant bacteria in a conventional municipal wastewater treatment plant. Sci. Total Environ. 421-422: 173-183. http://dx.doi.org/10.1016/j.scitotenv.2012.01.061.

Gaze, W.H., Zhang, L., Abdouslam, N.A., Hawkey, P.M., Calvo-Bado, L., Royle, J., Brown, H., Davis, S., Kay, P., Boxall, A.B.A., Wellington, E.M., 2011. Impacts of anthropogenic activity on the ecology of class 1 integrons and integron-associated genes in the environment. ISME J. 5 (8):12531261. http://dx.doi.org/10.1038/ismej.2011.15

Gillings, M.R., Boucher, Y., Labbate, M., Holmes, A., Krishnan, S., Holley, M., Stokes, H.W., 2008. The evolution of class 1 integrons and the rise of antibiotic resistance. J. Bacteriol. 190:5095-5100. http://dx.doi.org/10.1128/JB.00152-08.

Gillings, M.R., Gazes, W.H., Pruden, A., Smalla, K., Tiedje, J.M., Zhu, Y.-G., 2015. Using the class 1 integron-integrase gene as a proxy for anthropogenic pollution. ISME J. 9: 1269-1279. http://dx.doi.org/10.1038/ismej.2014.226. 
Gros, M., Petrović, M., Barceló, D., 2007.Wastewater treatment plants as a pathway for aquatic contamination by pharmaceuticals in the Ebro river basin (northeast Spain). Environ. Toxicol. Chem. 26:1553-1562. http://dx.doi.org/10.1897/06-495R.1.

Gu, C., Karthikeyan, K.G., 2005. Interaction of tetracycline with aluminum and iron hydrous oxides. Environ. Sci. Technol. 39:2660-2667. http://dx.doi.org/10.1021/es048603o.

Hardwick, S.A., Stokes, H.W., Findlay, S., Taylor, M., Gillings, M.R., 2008. Quantification of class 1 integron abundance in natural environments using real-time quantitative PCR. FEMS Microbiol. Lett. 278:207-212. http://dx.doi.org/10.1111/j.1574-6968.

2007.00992.x

Huerta, B., Rodriguez-Mozaz, S., Nannou, C., Nakis, L., Ruhí, A., Acuña, V., Sabater, S., Barcelo, D., 2016. Determination of a broad spectrum of pharmaceuticals and endocrine disruptors in biofilm from a waste water treatment plant-impacted river. Sci. Total Environ. 540:241-249. http://dx.doi.org/10.1016/j.scitotenv.2015.05.049.

Jelić, A., Gros, M., Petrović, M., Ginebreda, A., Barceló, D., 2012. Occurrence and elimination of pharmaceuticals during conventional wastewater treatment. In: Guasch, H., Ginebreda, A., Geiszinger, A. (Eds.), Emerging and Priority Pollutants in Rivers, the Handbook of Environmental Chemistry. Springer Berlin Heidelberg, pp. 1-23.

Kasprzyk-Hordern, B., Dinsdale, R.M., Guwy, A.J., 2008. The occurrence of pharmaceuticals, personal care products, endocrine disruptors and illicit drugs in surface water in South Wales, UK. Water Res. 42:3498-3518. http://dx.doi.org/10.1016/j.watres.2008.04.026.

Khan, G.A., Berglund, B., Khan, K.M., Lindgren, P.-E., Fick, J., 2013. Occurrence and abundance of antibiotics and resistance genes in rivers, canal and near drug formulation facilities—a study in Pakistan. PLoS One 8, e62712. http://dx.doi.org/10.1371/journal.pone.0062712.

Kim, S.-C., Carlson, K., 2007. Temporal and spatial trends in the occurrence of human and veterinary antibiotics in aqueous and river sediment matrices. Environ. Sci. Technol. 41:50-57. http://dx.doi.org/10.1021/es060737+

Klappenbach, J.A., Saxman, P.R., Cole, J.R., Schmidt, T.M., 2001. Rrndb: the ribosomal RNA operon copy number database. Nucleic Acids Res. 29, $181-184$.

Kruskal, J.B., 1964. Nonmetric multidimensional scaling: a numerical method. Psychometrika 29:115-129. http://dx.doi.org/10.1007/BF02289694

Kümmerer, K., 2004. In: Kümmerer, K. (Ed.), Pharmaceuticals in the Environment—Source, Fate, Effects and Risks. Springer Berlin Heidelberg, NY.

LaPara, T.M., Burch, T.R., McNamara, P.J., Tan, D.T., Yan, M., Eichmiller, J.J., 2011. Tertiary-treated municipal wastewater is a significant point source of antibiotic resistance genes into Duluth-superior harbor. Environ. Sci. Technol. 45: 9543-9549. http://dx.doi.org/10.1021/es202775r.

Lindqvist, N., Tuhkanen, T., Kronberg, L., 2005. Occurrence of acidic pharmaceuticals in raw and treated sewages and in receiving waters. Water Res. 39:2219-2228. http://dx.doi.org/10.1016/j.watres.2005.04.003.

Ma, L., Zhang, X.-X., Cheng, S., Zhang, Z., Shi, P., Liu, B., Wu, B., Zhang, Y., 2011. Occurrence, abundance and elimination of class 1 integrons in one municipal sewage treatment plant. Ecotoxicology 20:968-973. http://dx.doi.org/10.1007/s10646-011-0652-y.

Martinez, J.L., 2009. Environmental pollution by antibiotics and by antibiotic resistance determinants. Environ. Pollut. 157:2893-2902 Barking Essex 1987. 10.1016/j.envpol.2009.05.051.

McLellan, S.L., Huse, S.M., Mueller-Spitz, S.R., Andreishcheva, E.N., Sogin,M.L., 2010. Diversity and population structure of sewage-derived microorganisms in wastewater treatment plant influent. Environ. Microbiol. 12:378-392. http://dx.doi.org/10.1111/j.1462-2920.2009.02075.x.

Miège, C., Choubert, J.M., Ribeiro, L., Eusebe, M., Coquery, M., 2009. Fate of pharmaceuticals and personal care products in wastewater treatment plants-conception of a database and first results. Environ. Pollut. 157:1721-1726 Barking Essex 1987. 10.1016/j.envpol.2008.11.045.

Paliy, O., Shankar, V., 2016. Application of multivariate statistical techniques in microbial ecology. Mol. Ecol. 25 (5):1032-1057. http://dx.doi.org/10.1111/mec.13536.

Park, J.-W., Crowley, D.E., 2006. Dynamic changes in nahAc gene copy numbers during degradation of naphthalene in PAH-contaminated soils. Appl. Microbiol. Biotechnol. 72:1322-1329. http://dx.doi.org/10.1007/s00253-006-0423-5.

Petrovic, M., De Alda, M.J.L., Diaz-Cruz, S., Postigo, C., Radjenovic, J., Gros, M., Barcelo, D., 2009. Fate and removal of pharmaceuticals and illicit drugs in conventional and membrane bioreactor wastewater treatment plants and by riverbank filtration. Phil. Trans. R. Soc. A 367:3979-4003. http://dx.doi.org/10.1098/rsta.2009.0105.

Pyl'nik, S.V., Dueck, J.H., Min'kov, L.L., 2007. Equilibrium thickness of a biofilm. Theor. Found. Chem. Eng. 41:430-435. http://dx.doi.org/10.1134/S004057950704015X.

Ramil, M., El Aref, T., Fink, G., Scheurer, M., Ternes, T.A., 2010. Fate of beta blockers in aquatic-sediment systems: sorption and biotransformation. Environ. Sci. Technol. 44:962-970. http://dx.doi.org/10.1021/es9027452.

Ramirez, A.J., Brain, R.A., Usenko, S., Mottaleb, M.A., O'Donnell, J.G., Stahl, L.L.,Wathen, J.B., Snyder, B.D., Pitt, J.L., Perez-Hurtado, P., Dobbins, L.L., Brooks, B.W., Chambliss, C.K., 2009. Occurrence of pharmaceuticals and personal care products in fish: results of a national pilot study in the United States. Environ. Toxicol. Chem. 28:2587-2597. http://dx.doi.org/10.1897/08-561.1.

Ricart, M., Guasch, H., Alberch, M., Barceló, D., Bonnineau, C., Geiszinger, A., Farré, M., Ferrer, J., Ricciardi, F., Romaní, A.M., Morin, S., Proia, L., Sala, L., Sureda, D., Sabater, S., 2010. Triclosan persistence through wastewater treatment plants and its potential toxic effects on river biofilms. Aquat. Toxicol. 100:346-353. http://dx.doi.org/10.1016/j.aquatox.2010.08.010.

Rizzo, L., Manaia, C., Merlin, C., Schwartz, T., Dagot, C., Ploy, M.C., Michael, I., Fatta-Kassinos, D., 2013. Urban wastewater treatment plants as hotspots for antibiotic resistant bacteria and genes spread into the environment: a review. Sci. Total Environ. 447:345-360. http://dx.doi.org/10.1016/j.scitotenv.2013.01.032.

Rosewarne, C.P., Pettigrove, V., Stokes, H.W., Parsons, Y.M., 2010. Class 1 integrons in benthic bacterial communities: abundance, association with Tn402-like transposition modules and evidence for co-selection with heavy-metal resistance. FEMS Microbiol. Ecol. 72:35-46. http://dx.doi.org/10.1111/j.1574-6941.2009.00823.x.

Rosi-Marshall, E.J., Kincaid, D.W., Bechtold, H.A., Royer, T.V., Rojas, M., Kelly, J.J., 2013. Pharmaceuticals suppress algal growth and microbial respiration and alter bacterial communities in stream biofilms. Ecol. Appl. 23:583-593. http://dx.doi.org/10.1890/12-0491.1.

Ruhí, A., Acuña, V., Barceló, D., Huerta, B., Mor, J.-R., Rodríguez-Mozaz, S., Sabater, S., 2016. Bioaccumulation and trophic magnification of pharmaceuticals and endocrine disruptors in a Mediterranean river food web. Sci. Total Environ. 540:250-259. http://dx.doi.org/10.1016/j.scitotenv.2015.06.009.

Sacher, F., Lange, F.T., Brauch, H.J., Blankenhorn, I., 2001. Pharmaceuticals in groundwaters analytical methods and results of a monitoring program in Baden-Württemberg, Germany. J. Chromatogr. A 938, 199-210.

Sanchez,W., Sremski,W., Piccini, B., Palluel, O., Maillot-Maréchal, E., Betoulle, S., Jaffal, A., Aït-Aïssa, S., Brion, F., Thybaud, E., Hinfray, N., Porcher, J.-M., 2011. Adverse effects in wild fish living downstream from pharmaceutical manufacture discharges. Environ. Int. 37:1342-1348. http://dx.doi.org/10.1016/j.envint.2011.06.002.

Scheurell, M., Franke, S., Shah, R.M., Hühnerfuss, H., 2009. Occurrence of diclofenac and its metabolites in surface water and effluent samples from Karachi, Pakistan. Chemosphere 77:870-876. http://dx.doi.org/10.1016/j.chemosphere.2009.07.066.

Scheytt, T.,Mersmann, P., Lindstädt, R., Heberer, T., 2005. Determination of sorption coefficients of pharmaceutically active substances carbamazepine, diclofenac, and ibuprofen, in sandy sediments. Chemosphere 60:245-253. http://dx.doi.org/10.1016/j. chemosphere.2004.12.042.

da Silva, B.F., Jelic, A., López-Serna, R., Mozeto, A.A., Petrovic, M., Barceló, D., 2011. Occurrence and distribution of pharmaceuticals in surface water, suspended solids and sediments of the Ebro river basin, Spain. Chemosphere 85:1331-1339. http://dx.doi.org/10.1016/j.chemosphere.2011.07.051.

Simo Tchuinte, P.L., Stalder, T., Venditti, S., Ngandjio, A., Dagot, C., Ploy, M.-C., Barraud, O., 2016. Characterisation of class 3 integrons with oxacillinase gene cassettes in hospital sewage and sludge samples from France and Luxembourg. Int. J. Antimicrob. Agents In Press. 10.1016/j.ijantimicag.2016.06.018

Stalder, T., Barraud, O., Casellas, M., Dagot, C., Ploy, M.-C., 2012. Integron involvement in environmental spread of antibiotic resistance. Front. Microbiol. 3:119. http://dx.doi. org/10.3389/fmicb.2012.00119. 
Stalder, T., Alrhmoun,M., Louvet, J.N., Casellas,M.,Maftah, C., Carrion, C., Pons,M.-N., Pahl, O., Ploy, M.-C., Dagot, C., 2013. Dynamic assessment of the floc morphology, bacterial diversity and integron content of an activated sludge reactor processing hospital effluent. Environ. Sci. Technol. 47 (14):7909-7917. http://dx.doi.org/10.1021/es4008646.

Stalder, T., Barraud, O., Jové, T., Casellas, M., Gaschet, M., Dagot, C., Ploy,M.C., 2014. Quantitative and qualitative impact of hospital effluent on dissemination of the integrin pool. ISME J. 8 (4):768-777. http://dx.doi.org/10.1038/ismej.2013.189.

Sui, Q., Cao, X., Lu, S., Zhao,W., Qiu, Z., Yu, G., 2015. Occurrence, sources and fate of pharmaceuticals and personal care products in the groundwater: a review. Emerg. Contam. 1:14-24. http://dx.doi.org/10.1016/j.emcon.2015.07.001.

Uyaguari, M.I., Fichot, E.B., Scott, G.I., Norman, R.S., 2011. Characterization and quantitation of a novel $\beta$-lactamase gene found in a wastewater treatment facility and the surrounding coastal ecosystem. Appl. Environ. Microbiol. 77 (23):8226-8233. http://dx.doi.org/10.1128/AEM.02732-10.

Vieno, N., Tuhkanen, T., Kronberg, L., 2007. Elimination of pharmaceuticals in sewage treatment plants in Finland. Water Res. 41:1001-1012. http://dx.doi.org/10.1016/j.watres.2006.12.017.

Wellington, E.M., Boxall, A.B., Cross, P., Feil, E.J., Gaze, W.H., Hawkey, P.M., Johnson-Rollings, A.S., Jones, D.L., Lee, N.M., Otten, W., Thomas, C.M., Williams, A.P., 2013. The role of the natural environment in the emergence of antibiotic resistance in gram-negative bacteria. Lancet Infect. Dis. 13 (2):155-165. http://dx.doi.org/10.1016/S1473-3099(12)70317-1.

Wéry, N., Monteil, C., Pourcher, A.-M., Godon, J.-J., 2010. Human-specific fecal bacteria in wastewater treatment plant effluents. Water Res. 44:18731883. http://dx.doi.org/10.1016/j.watres.2009.11.027.

Wright, M.S., Baker-Austin, C., Lindell, A.H., Stepanauskas, R., Stokes, H.W., McArthur, J.V., 2008. Influence of industrial contamination on mobile genetic elements: class 1 integron abundance and gene cassette structure in aquatic bacterial communities.

ISME J. 2:417-428. http://dx.doi.org/10.1038/ismej.2008.8.

Wishart, D.S., Knox, C., Guo, A.C., Shrivastava, S., Hassanali, M., Stothard, P., Chang, Z., Woolsey, J., 2006. Drug Bank: a comprehensive resource for in silico drug discovery and exploration. Nucleic Acids Res. 1 (34) ((Database issue):D668-72. http://www.drugbank.ca/). 